\title{
A EDUCAC̣ÃO ESTÉTICA EM FRIEDRICH SCHILLER
}

\section{Carina Zanelato Silva ${ }^{1}$}

\begin{abstract}
Friedrich Schiller's aesthetic theory (1759-1805) approached art as a means of educating men for freedom, served as the basis for his literary production, which aims to accomplish the principles theorized in his philosophy. The permeation between literature and philosophy allowed, in Schiller's theories, the idealization of the steps that should be taken by the French Revolution and permitted the opening for a revolution of the spirit, which would be essential for the generation of romantics that was on the rise. Moreover, this theory gave opportunity to a new vision of art, which has utility in itself, and, from that autonomy, Schiller established the theater, more specifically the tragedy as a moral institution, capable of providing the man the ability for freedom.
\end{abstract}

Keywords: Philosophy; literature; aesthetics education; Friedrich Schiller.

Resumo: A teoria estética de Friedrich Schiller (1759-1805) abordou a arte como meio de educar o homem para a liberdade, e serviu de base para a sua produção literária, que busca realizar os princípios teorizados em sua filosofia. A permeação entre literatura e filosofia permitiu em Schiller a idealização dos passos que deveriam ser dados pela Revolução Francesa e possibilitou a abertura para uma revolução do espírito, que seria primordial para a geração dos românticos que estava em ascensão. Além disso, essa teoria deu ensejo a uma visão de arte que possui utilidade em si mesma, e, a partir dessa autonomia, Schiller estabeleceu o teatro, mais especificamente a tragédia, como instituição moral, capaz de proporcionar ao homem a aptidão para a liberdade.

Palavras-chave: Filosofia; literatura; educação estética; Friedrich Schiller.

$\mathrm{Na}$ arte alemã, o período conhecido como Kunstperiode ("período da arte") compreendeu quatro grandes correntes literárias que de certo modo trazem pontos antagônicos entre si, mas que também compartilham traços significativos. Assim, Aufklärung, Sturm und Drang, Classicismo de Weimar e Romantismo têm seus próprios projetos e ideários, mas caracterizam-se como movimentos que transfiguraram os

${ }^{1}$ Doutoranda UNESP - carinazs@hotmail.com 
12 | Carina Zanelato Silva

valores barrocos e mudaram o foco literário para a investigação do ser humano, suas emoções, seu caráter, sua razão. Friedrich Schiller (1759. 1805), um dos principais expoentes desse período, contribuiu inicialmente para o ímpeto avassalador do Sturm und Drang, em especial com sua peça Os bandoleiros (1781), e, alguns anos mais tarde, integrou o período literário denominado Classicismo de Weimar, voltando-se para a arte baseada nos valores estéticos da Antiguidade, na harmonia, na beleza e na perfeição. Essa corrente literária geralmente tem seu início marcado pela viagem de Goethe à Itália nos anos 1786-1788, e pode ser considerada clássica tanto pelo apogeu da produção literária na Alemanha, coroada pelas obras de Schiller e Goethe, quanto como referência a um estilo pautado nos valores da Antiguidade Clássica (cf. ROSENFELD, 1993). Nesse período, os dois autores desenvolveram obras literárias e filosóficas que visam à harmonia, à contenção dos ímpetos e que se inspiram no humanismo grego para a conciliação do homem moderno fragmentado.

Contudo, o classicismo presente na teoria estética de Schiller vai muito além de um mero "retorno" à Antiguidade Clássica e de um simples resgate de valores, pois a eles se acrescentam "a vivência do Sturm und Drang" (RÖHL, 1986), o contato com Goethe e a filosofia kantiana, superando as experiências humanistas anteriores (Martin Opitz no Barroco e Johann Christoph Gottsched na Aufklärung), e instituindo o caminho da formação do homem rumo à liberdade. Este classicismo vem imbuído de um disciplinamento dos violentos impulsos do Sturm und Drang e da procura da harmonização das tensões, rumo à serenidade apolínea, que por sua vez, será fonte de grande crítica entre os românticos, que começam a se manifestar por volta de $1797-1798 .{ }^{2} \mathrm{O}$ Romantismo nascente teve seus horizontes ampliados pelas teorias estéticas de Schiller e Goethe, principalmente a teoria do jogo desenvolvida por Schiller, que foi, segundo Safranski (2010, p. 41), "o prelúdio da revolução literária romântica em torno de 1800”, ainda que os românticos não admitissem tais influências.

Segundo Peter Szondi, em sua Teoria do drama moderno (1956), as primeiras doutrinas do drama (Aristóteles) tinham a forma como algo préestabelecido, que necessitava de uma matéria adequada para poder

\footnotetext{
${ }^{2}$ Não é raro encontrarmos a classificação de Goethe e Schiller como românticos, embora o trabalhos desenvolvidos pelos escritores sejam claramente de cunho clássico. Sobre o assunto, ver ROSENFELD, A. Schiller. In: Teatro moderno. São Paulo: Perspectiva, 2008, p. 19-41.
} 
realizar-se. Nas relações entre forma e conteúdo, a forma, nesta concepção, não estava ligada à história, o que implicava a sua possibilidade em qualquer tempo, desde que o conteúdo aplicado a ela fosse condizente. Assim, o autor cita Goethe e Schiller (2001, p. 23) e o seu classicismo como instâncias que tentaram manter essa concepção nãodialética de forma e conteúdo. A esse tipo de drama, Szondi classificou de "drama absoluto", que se baseia em uma "relação pura" entre forma e conteúdo, ou seja, o drama absoluto é "desligado de tudo o que lhe é externo. Ele não conhece nada além de si” (SZONDI, 2001, p. 30).

Dessa forma, o drama absoluto caracteriza-se por uma série de normatizações que marcam o seu aspecto não-dialético, como por exemplo a relação entre o espectador e o drama, que deve manter as duas instâncias dentro dos limites que lhes cabem, sem que um interfira no outro (SZONDI, 2001, p. 30); ou a perfeita identidade entre o ator e a personagem que ele representa; ou até mesmo a configuração do palco, que só deve ser percebido pelo espectador quando o espetáculo começa.

Porém, Hegel em sua Estética, segundo Szondi (2001, p. 26),

Ao colocar em evidência o que "precipitou" na forma dramática como enunciado sobre a existência humana, ele faz de um fenômeno da história literária um documento da história da humanidade. Deve-se mostrar as exigências técnicas do drama como reflexo de exigências existenciais [...].

Hegel, com este pensamento, evidenciou o aniquilamento dessa oposição atemporal entre forma e conteúdo e abriu caminho para uma historicização dos gêneros poéticos, o que permitiu a existência da contradição entre forma e conteúdo, pois este conteúdo aplicado à forma passou a exigir da mesma um respaldo, o que gerou um conflito entre estas duas instâncias (SZONDI, 2001, p. 24). Assim, a crise do drama no final do século XIX está intrinsecamente ligada à impossibilidade de se manter os aspectos do drama absoluto: o questionamento da velha forma reflete a sua não possibilidade na sociedade moderna.

Friedrich Schiller, portanto, foi classificado por Szondi como um dos que tentaram manter essa forma dramática absoluta. $\mathrm{O}$ autor iniciou seus trabalhos sobre a tragédia no ano de 1790 e os resultados obtidos foram inúmeros ensaios que tentam determinar o lugar e a função da arte dentro de um contexto social, e que abordam como a arte trágica pode resultar de grande importância para formação do homem. Dentre estes 


\section{4 | Carina Zanelato Silva}

ensaios estão Sobre graça e dignidade, A educação estética do homem, Sobre poesia ingênua e sentimental, Teoria da tragédia ${ }^{3}$, a série de cartas Kallias ou sobre a beleza e os Fragmentos das preleções sobre estética do semestre de inverno de 1792-93, coletados por Christian Friedrich Michaelis, que são fundamentais para se entender a obra do autor como mantenedora dessa forma pura dramática, mas também como fator evidente de sua tomada de posição diante da obra de Kant, da Aufklärung (Iluminismo) e da Revolução Francesa (cf. BARBOSA, 2004).

Impressionados pela grandiosidade com que a Revolução Francesa se mostrou ao mundo no ano de 1789 , os intelectuais alemães se viram diante de uma mudança notável, que significava o começo de uma nova era. Nunca se vira uma revolta popular de tamanha proporção e "a imagem da revolução como luz do dia ou alvorada se encontra em quase todos os escritores do início dos anos 1790” (SAFRANSKI, 2010, p. 34). Inicialmente entusiastas do movimento, a Revolução deu asas à produção artística na Alemanha e impulsionou o idealismo nascente. Surgiram diversas publicações a respeito dos acontecimentos e escritores como Kant, Fichte, Schlegel e Novalis viam nesses acontecimentos a possibilidade da revolução através do pensamento, ou seja, através da prática dos ideários filosóficos de igualdade e liberdade que os iluministas haviam teorizado. Porém, a esse entusiasmo se seguiu o terror e a opressão, e logo a liberdade propagada caiu em descrédito:

A degeneração da Revolução em terror não só atestaria o relativo fracasso da Aufklärung como daria a verdadeira dimensão da tarefa histórica a ser enfrentada: a da formação do homem para a liberdade. (BARBOSA, 2004, p. 23)

Assim como grande parte dos intelectuais alemães, Friedrich Schiller sentiu-se atraído e repelido pela Revolução, e suas obras filosóficas e literárias foram o meio utilizado pelo autor para o debate do

\footnotetext{
${ }^{3} \mathrm{O}$ volume Teoria da tragédia é a reunião pela editora E.P.U. dos textos Über den Grund des Vergnügens an tragischen Gegenständen ("Acerca da razão por que nos entretêm assuntos trágicos”); Die Schaubühne als eine moralische Anstatt betrachtet ("O teatro considerado como instituição moral”); Über das Erhabene ("Acerca do sublime”); Über den Gebrauch des Chors in der Tragödie ("Acerca do uso do coro na tragédia”); Über die tragische Kunst ("Acerca da arte trágica”); e Über das Pathetische (“Acerca do patético").
} 
assunto. Diante do terror, ele tentou incluir a Revolução no mundo da filosofia e propôs em seus ensaios uma revolução estética que tinha o propósito de tornar as pessoas hábeis à liberdade, pois, como mostravam os acontecimentos, ao conquistar a liberdade almejada, as pessoas não sabiam como usá-la, e as consequências eram funestas.

Desse entusiasmo surgiu a teoria do jogo de Schiller, que foi de fundamental importância para os desdobramentos de seus estudos estéticos. O homem, segundo o autor, é movido por três instâncias que dele fazem exigências. A primeira delas é o sensível: o homem como ser físico sofre exigências da natureza. A segunda é a razão, pois "ele é um ser que sente racionalmente" (SCHILLER, 1992, p. 117), e por isso não se deve deixar dominar pela natureza, mas sim dominá-la. A terceira é o decoro, que exige dele "respeito pela sociedade e a obrigação de comportar-se como um ser civilizado" (SCHILLER, 1992, p. 117). A teoria do jogo se baseia nessas instâncias em interação. Segundo Schiller (2002), somente no jogo, em estado lúdico, o homem se desenvolve plenamente, pois é neste estado que o sensível e a razão operam conjuntamente, recuperando-o da fragmentação que o separou da essência una de que era constituído o seu ser. $\mathrm{O}$ autor argumenta que o humanismo grego era perfeito, porque estas instâncias estavam em completa harmonia no homem, e, a separação, a fragmentação das ciências, arte e religião fragmentaram o homem moderno (SCHILLER, 2002, p. 37):

Divorciaram-se o Estado e a Igreja, as leis e os costumes; a fruição foi separada do trabalho; o meio, do fim; o esforço, da recompensa. Eternamente acorrentado a um pequeno fragmento do todo, o homem só pode formar-se enquanto fragmento; ouvindo eternamente o mesmo ruído monótono da roda que ele aciona, não desenvolve a harmonia de seu ser e, em lugar de imprimir a humanidade em sua natureza, torna-se mera reprodução de sua ocupação, de sua ciência. [...] A letra morta substitui o entendimento vivo, a memória bem treinada é guia mais seguro que gênio e sensibilidade.

Ele acredita que a causadora dessa "ferida na humanidade moderna" foi a própria cultura, que ampliou a experiência e o pensamento mais preciso, abrindo espaço para a separação destas esferas. A fragmentação, portanto, ocasionou a oposição, antes inexistente, entre 
o estado sensível e a razão; abrir mão da unicidade do ser, entretanto, foi o caminho necessário e inevitável para a progressão da espécie. A ampliação do entendimento e o acúmulo de conhecimento desembocariam inevitavelmente na fragmentação entre o sensível e a razão, pois somente colocando em oposição essas duas instâncias, consegue-se desenvolver as múltiplas potencialidades do homem (2002, p. 40). Antes mesmo de Marx, Schiller antecipa a alienação que a divisão do trabalho provocou no homem moderno, e coloca nesse homem a função de "restabelecer em nossa natureza, através de uma arte mais elevada, essa totalidade que foi destruída pelo artifício” (2002, p. 41). A revolução do espírito proposta pelo autor buscará, então, na arte a fonte de aprimoramento dos sentimentos humanos, a base para a formação do homem na liberdade.

Assim, a teoria do jogo baseia-se na seguinte questão: segundo Schiller (2002), o homem somente ratifica a sua humanidade em estado lúdico, pois é neste estado que confirmamos ter saído do estado animal e entrado em estado de cultura (SCHILLER, 2002, p. 130):

E qual o fenômeno que anuncia no selvagem o advento da humanidade? Por muito que indaguemos à história, encontramos sempre a mesma resposta para os povos todos que tenham emergido da escravidão do estado animal: a alegria com a aparência, a inclinação para o enfeite e para o jogo.

Quando ainda em estado animal, o homem utiliza apenas os seus sentidos (olfato, visão, tato, audição, paladar) na fruição. A partir do momento em que esses sentidos já não são suficientes e ele busca na fruição um valor autônomo, o homem passa deste estado animal para um estado estético, despertando, assim, o impulso lúdico. Desse impulso lúdico advém o impulso mimético, e o homem se faz capaz de distinguir realidade e aparência, e essa passagem do natural, do sensível para o estético tem de se dar justamente pela sensibilidade primária, pois através (SCHILLER, 2002, p. 137)

Desse jogo da livre sequencia das ideias, de natureza ainda inteiramente material e explicado por meras leis naturais, a imaginação dá o salto em direção do jogo estético, na busca de uma forma liure. Tem-se de chamá-lo salto, porque uma força totalmente nova se põe em ação aqui; o espírito 
legislador intervém pela primeira vez nas ações do cego instinto; submete o procedimento arbitrário da imaginação à sua unidade eterna e imutável, coloca sua espontaneidade no que é mutável e sua infinitude no que é sensível.

Ao estabelecer os passos do salto estético que o ser humano dá em relação ao seu estado animal, Schiller diz que mesmo imerso em cultura, o homem ainda possui o seu estado natural, e, portanto, suas necessidades físicas fazem parte de sua humanidade. Na distinção destas categorias que começam a emergir no homem de cultura, Schiller (2002) caracteriza três impulsos: o sensível, o formal e o lúdico.

O impulso sensível constitui-se da parte física do homem. Ele é a matéria que preenche o tempo e que está limitada a ele, é a força da natureza que impõe a necessidade, que lhe exige realidade na existência. Este impulso é o que, segundo Schiller (2002) impede ao homem a perfeição, a elevação à divindade, pois mesmo que por momentos ele consiga driblá-lo, logo a força da natureza retoma seu direito e lhe impõe necessidades. Já o impulso formal é a parte racional do homem, que não está subjugada ao tempo e que lhe permite a liberdade, a ampliação do ser; é este impulso que rege as leis morais. Ao atuarem conjuntamente impulso sensível e formal, o homem consegue recuperar a harmonia perdida e ter liberdade. Esta harmonia, segundo Schiller (2002), somente é conseguida em estado lúdico, que "imporá necessidade ao espírito física e moralmente a um só tempo; pela supressão de toda contingência ele suprimirá, portanto, toda necessidade, libertando o homem tanto moral quanto fisicamente" (SCHILLER, 2002, p. 74).

O jogo entre os impulsos determina este estado lúdico e a beleza é a causa e o produto do jogo. É ela que faz com que o homem caminhe do sensível ao formal e do formal ao sensível, pois liga duas categorias que se opõem; não há atritos entre estas instâncias: uma se deixa conduzir pela outra. A matéria estética (SCHILLER, 2002, p. 109), dessa forma, conduz o homem ao ilimitado e lhe permite a humanidade plena, como se ele ainda não tivesse sofrido a ruptura, a fragmentação. Como segunda criadora do homem, a beleza capacita-o para a humanidade, porém, o que a diferencia da natureza, sua primeira criadora, é a abertura para a livre escolha: cabe à própria vontade do homem o uso ou não da mesma. A liberdade, alvo primordial das considerações de Schiller sobre a educação estética do homem, advém da oposição dos impulsos fundamentais que agem no homem. Ela é expressão da vontade que exerce sobre os impulsos o seu poder. Nem impulso formal nem impulso sensível podem 
desempenhar um sobre o outro coação ou imposição através do poder; apenas a vontade do homem deve legislar sobre os dois. Assim, a apreciação estética do belo causa um agrado livre, desinteressado, livre de propósitos vitais; nossos impulsos sensíveis se harmonizam com a razão, e é nessa harmonia que a nossa liberdade transparece; sentimos no objeto belo a nossa liberdade dentro da natureza. Mas a beleza também é o efeito da harmonia entre a natureza e o ideal, pois abrange todas as capacidades do ser humano em sua completude, deixando livre todas as suas forças. Por isso, o estado lúdico proporcionado pela arte, além de dar ensejo ao entretenimento, permite ao homem retomar a liberdade, o humanismo perdido na fragmentação: "A humanidade perdeu sua dignidade, mas a arte a salvou e conservou em pedras insignes; a verdade subsiste na ilusão, da cópia será refeita a imagem original" (SCHILLER, 2002, p. 50).

Não podemos deixar de mencionar que a teoria do jogo de Schiller parte da teoria de Kant sobre o "jogo lúdico livre", e em sua maior parte se assemelha a ela (KORFMANN, 2004, p. 29-30):

$\mathrm{Na}$ comunicação com o texto poético, experimentamos, desprendidos dos sentidos e do intelecto discursivo, uma plenitude do mundo impossível de alcançar na vida empírica. [...] a experiência estética neutraliza, conforme Kant, os dois pólos, os sentidos e a razão, e consegue transformá-los num estado de "jogo lúdico livre" em que a razão retira dos sentidos seu rigoroso caráter imediato (Unmittelbarkeit), enquanto os sentidos retiram da razão sua obrigatoriedade de atuar em conceitos (Begriffszwang). Acontece, então, na experiência estética um balanceamento (Ausgleich) de sentido e razão. O julgamento do belo inicia o mecanismo geral do conhecimento de conceber algo singular sob um conceito geral sem que se fixe o específico num conceito final. [...] Julgamentos de gosto não são mais legitimados através de convenções diferenciadas hierarquicamente, mas se baseiam num fenômeno humano geral, o conjunto das faculdades de conhecimento.

Em Kant (2002) a neutralização dos polos sensível e racional no homem é iniciada por um objeto belo, mas, ainda que essa neutralização se dê entre os polos sensível e racional, o que garante o "jogo lúdico livre" é a associação que a imaginação faz com o entendimento, duas faculdades 
de conhecimento, das quais é produzida a sensação de prazer ou desprazer. Kant, portanto, caracteriza o jogo naquele espaço em que a imaginação apreende um objeto e transporta-o ao entendimento que dele fará um conceito indeterminado. Já em Schiller o jogo entre os impulsos sensível e racional determina este estado de conciliação, e a beleza é a causa e o produto do jogo. É ela que faz com que o homem caminhe do sensivel ao formal e do formal ao sensível, pois liga duas categorias que se opõem; não há atritos entre estas instâncias: uma se deixa conduzir pela outra, unindo a vida do impulso sensível à forma do impulso formal, e traduzindo a beleza em forma viva. Entretanto esse equilíbrio perfeito dos impulsos opostos somente é possível em um Ideal. A realidade não consegue alcançar esta perfeição, sobressaindo sempre um impulso sobre o outro; enquanto a beleza ideal permanece una e indivisível, a beleza na experiência terá a variação dupla de um instinto a outro (SCHILLER, 2002, p. 84):

[...] se pode esperar do belo um efeito dissolvente e outro de tensão: um dissolvente para manter em seus limites tanto o impulso sensível quanto o formal; um tensionante, para assegurar os dois a sua força. Essas espécies de efeito da beleza, contudo, devem ser uma só segundo a Idéia. Ela deve dissolver quando faz igualmente tensas as duas naturezas, e deve dar tensão quando as dissolve por igual. [...] O que no belo ideal é distinguido apenas na representação, no belo da experiência é diferente segundo a existência.

Os dois tipos de beleza na experiência acima descritos partem da maneira em que estão dispostos os impulsos no homem. O homem que é coagido tanto pelo impulso sensível quanto pelo impulso formal quando se vê dominado por qualquer um destes dois impulsos participa do belo com efeito de tensão, ou como denomina Schiller, da beleza enérgica, pois para ele a dominação de qualquer um dos impulsos caracteriza um estado de violência. O homem que é dominado por apenas um dos impulsos participa do belo com efeito dissolvente, ou beleza suavizante, em que o impulso dominante é dissolvido pela forma, no caso do impulso sensível, ou pela matéria, no caso do impulso formal.

Mesmo sem a unicidade da beleza Ideal, a beleza na experiência partilha dos dois mundos: com ela adentramos o mundo das Ideias sem abandonar o mundo sensível. Já no acúmulo de conhecimento a 
representação pode se afastar do sensível sem que isso cause prejuízo ao deleite através da verdade. Schiller (2202) deixa claro que podemos passar de um estado sensível a um estado racional através do conhecimento, mas, ao contrário da beleza, aquele não comprova a subsistência e a atuação conjunta dos dois estados. Exclui-se do pensamento o sentimento, e do sentimento o pensamento, ressaltando, assim, suas características opositivas. Portanto a beleza sustenta a possibilidade de liberdade moral na medida em que garante a simultaneidade das duas leis que regem o homem: o sensível e o formal.

Na contemplação (SCHILLER, 2002) o homem é despertado pela beleza de um objeto que o suspende temporalmente, e a forma desse objeto lhe reflete a imagem do infinito. A imagem o liberta da mera sensação e o faz ter consciência do exterior, ocasionando a reflexão. $\mathrm{O}$ advento do pensamento faz com que de dominado pela natureza, ele passe a ser o seu observador e, portanto, ela se torna seu objeto de contemplação. A escuridão exterior que o atormentava ganha forma e clareza através do pensamento: a reflexão liga-se tão perfeitamente ao sentimento, que parece que sentimos a forma. A beleza "é, portanto, forma, pois que a contemplamos, mas é, ao mesmo tempo, vida, pois que a sentimos. Numa palavra: é, simultaneamente, nosso estado e nossa ação" (SCHILLER, 2002, p. 127).

Diante de tal perspectiva e, sendo a tragédia a "imitação de uma ação digna de compaixão” (SCHILLER, 1992, p. 106), Schiller elege esta forma como a melhor maneira de suscitar no homem o gosto pela liberdade. Segundo o autor, a tragédia é da categoria de entretenimento que proporciona o deleite moral do homem, que somente é alcançado através do uso de meios morais. Ela tem o efeito de fazer-nos sentir na capacidade do personagem a nossa capacidade de imposição da moral diante do impulso natural, e, ao sustentar a sua autonomia como objeto de entretenimento, a tragédia pode exercer a sua função moral e educativa, não visando o fim moral em si mesmo, mas chegando a ele através da plena liberdade estética.

Schiller leu a Poética em 1797 e em seus estudos sobre a tragédia ressoam algumas das categorias de que fala Aristóteles, porém elas não predominam tanto quanto a filosofia de Kant. Através de Kant, Schiller, segundo Rosenfeld (1992), procura abordar em seus ensaios a "relação entre as esferas moral, estética e a do mero prazer sensível" (ROSENFELD, 1992, p. 9), que de um lado vê a arte como autônoma, mas que também a liga à moral. 
Disso resulta que Schiller, através do conceito kantiano de Zweckmäßigkeit (adequação a fins), formula uma concepção de estética em que a natureza é subordinada ao mundo da liberdade. Segundo o autor (1992), o ser humano tem como base do seu entretenimento o estado de emoção e, predisposto a ser atraído por sentimentos que suscitam horror, temor e tristeza, a emoção desagradável é a que mais lhe proporciona prazer. Mas por que nos sentimos atraídos pelo desagradável? A tragédia coloca diante dos nossos olhos um herói que padece, mas que ao mesmo tempo nos faz sentir um prazer sublime na disposição moral de seu caráter. Esse prazer suscitado provém de um acontecimento carregado de dor e sofrimento, e nisso temos uma inadequação que se torna adequada na medida em que a disposição moral do personagem luta contra o sofrimento. Somente através da inadequação causada por essa dor é que conseguimos uma adequação moral; temos que ferir o sensível para que o suprassensível se manifeste, e temos que combater os sofrimentos causados no sensível buscando ajuda na força moral. "Só a resistência pode tornar visível a força” (SCHILLER, 1992, p. 21), e essa resistência ao sofrimento pode ser medida pela intensidade do mesmo. Quanto mais intenso for o sofrimento, maior é o poder de resistência que deve ser empregado. E quando o sofrimento se torna dor muda e intensa, tão mais nobre é o resultado que se tem dessa resistência, e o entretenimento será tão mais livre quanto o prazer que provier dessa inadequação que é uma adequação a fins (Zweckmäßigkeit).

A tragédia incide em prazer na compaixão, e as categorias que produzem essa adequação a fins são o comovente e o sublime. Elas causam "prazer através do desprazer" (SCHILLER, 1992, p. 19), que fere a nossa faculdade sensível, mas nos faz tomar consciência de uma faculdade em nós superior, que desperta um status de elevação por um bem supremo e que em nada supera o prazer que sentimos nessa inadequação adequada.

$\mathrm{Na}$ tragédia (SCHILLER, 1992) sentimos esta inadequação quando vemos o herói sofrer: uma vez que se trata de um ser virtuoso, seu sofrimento comove-nos dolorosamente porque contraria a natureza do destino de um homem com tal caráter, o que também nos causa sofrimento. Porém, esse descompasso torna-se apropriado, visto que o sofrimento é combatido pela força moral: a conjunção de sentimentos contrários é a base de nossa independência moral. Mais que a harmonização do sensível e do racional proveniente do estado lúdico, a tragédia nos faz superar a conciliação entre os impulsos e nos eleva à categoria em que a força moral, a vontade prevalece ao sensível e ao 
formal. Aqui não há harmonia entre razão e sensibilidade, mas sim o triunfo do homem moral sobre o sensível.

O prazer é proveniente da faculdade moral, e por isso é sublime. $\mathrm{O}$ sublime nos faz sentir livres na medida em que os impulsos sensíveis já não fazem frente à razão, que por sua vez se deixa governar por uma instituição suprassensível: a vontade; somente ela agora prevalece diante dos impulsos. O homem, segundo Schiller (1992) não se iguala aos animais pois, além da necessidade natural, há nele uma instância que se chama vontade, que não está submetida nem ao sensível nem à razão, embora esteja aliada a esta. E o sublime é a mescla de dois sentimentos em si contraditórios: o "estar-dorido" e o "estar-alegre"; quando unidos, expressam a nossa liberdade moral diante do sensível, pois conseguimos mostrar nossa autonomia em relação à natureza.

Entretanto, Schiller nos diz que não devemos confundir o efeito proporcionado pela tragédia com o seu fim. Segundo o autor, as belasartes: "têm o fim comum de prodigalizar entretenimento e tornar felizes as pessoas" (1992, p. 14); porém, na tentativa de elevar as belas-artes, atribuem a ela um fim moral que primordialmente lhe é estranho. A arte é da categoria do entretenimento que proporciona o deleite moral do homem e não o contrário. Para se chegar a essa categoria, o caminho percorrido deve passar pelo da moralidade, ou seja, a arte deve utilizar meios morais que alcancem o entretenimento. Ao afirmar a sua autonomia é que ela pode exercer a sua função moral e educativa, não visando a moral, mas chegando a ela através da plena liberdade estética da arte, porque quando alcança a sua perfeição estética ela atinge indiretamente a sua capacidade moral e educativa. Essa capacidade é o efeito da arte, e não o seu fim. Assim, a função da tragédia consiste em (ROSENFELD, 1992, p. 10)

representar sensivelmente o supra-sensível ou de modo visível o invisível; representar, portanto, em termos cênicos, a liberdade do mundo moral [....] mostrando a vontade humana em choque com o despotismo dos instintos.

Fonte do prazer na dor, a tragédia é o deleite que consegue transpor os impulsos sensível e formal, proporcionando entretenimento a partir de meios morais; só assim ela pode ser considerada como uma instituição que torna oportuna a educação do homem para a liberdade.

Partindo para a produção literária do autor, essa teoria estética é transposta para o plano literário através de obras que possuem um caráter 
exemplificador. Nas tragédias Die Jungfrau von Orleans (A donzela de Orleans, 1801) e Maria Stuart (1800), o autor elabora estes conceitos através de figuras que nos precisam a ideia de homem clássico: ao mesmo tempo em que as heroínas buscam por liberdade, elas controlam o ímpeto e reconhecem na conciliação dos impulsos a liberdade que só pode ser alcançada através do equilíbrio. Elas ultrapassam a existência para, no gozo da morte, triunfar a liberdade almejada.

Para o desenvolvimento dessa capacidade educativa do teatro, há que se construir personagens que possibilitem ao leitor/espectador uma aproximação de ações e de entendimento, e não é ao acaso que a identificação destas duas instâncias é essencial. É nessa identificação que sentiremos a dor sensível suscitada no personagem e consequentemente sua elevação moral diante de tal dor. $\mathrm{O}$ entretenimento de que participa o espectador é livre na medida em que mantém "ativas as faculdades espirituais, a razão e a imaginação" (SCHILLER, 1992, p. 16); o teatro é a forma de arte que dá ao homem "sustento a toda faculdade da alma, sem sobrecarregar a uma única que seja, e unindo, ainda, à formação do entendimento e do coração, o mais sublime entretenimento" (SCHILLER, 1992, p. 34)

Ainda assim, para surtir o efeito esperado, essa desgraça (cf. SCHILLER, 1992, p. 93) não deve ser proveniente de fontes morais ou de uma "vontade depravada", mas sim de fatos exteriores, que não estão relacionados ou submetidos a uma vontade. Nestes casos, a compaixão suscitada será "mais pura".

A tragédia Maria Stuart gira em torno do conflito político-religiosofamiliar das rainhas Elizabeth Tudor e Maria Stuart. A rainha escocesa, criada na França, foge do país em busca de asilo na Inglaterra, pois matou seu marido Darnley por causa de um amante. Quando Maria Stuart chega à Inglaterra, Elizabeth se sente ameaçada, com a possível contestação de seu trono pela escocesa, pois, como filha de Henrique VIII com Ana Bolena, o casamento dos pais de Elizabeth poderia ser anulado caso a Igreja Católica o considerasse ilegal, uma vez que Catarina de Aragão (primeira esposa de Henrique VIII) ainda estava viva quando ocorreu o casamento. Sendo Maria Stuart bisneta de Henrique VII e neta de Margaret Tudor, irmã mais velha de Henrique VIII, a rainha escocesa poderia ser coroada, já que era a seguinte na linha de sucessão ao trono inglês, e Elizabeth seria considerada filha bastarda do rei.

O argumento da peça se dá, então, pelo encarceramento de Maria Stuart pela rainha inglesa. Com medo de cumprir a condenação de morte devido às represálias que seu país protestante poderia sofrer pela Igreja 


\section{4 | Carina Zanelato Silva}

Católica, à qual Maria estava filiada, a peça toda se desenvolve em torno da tensão que se estabelece entre as duas rainhas. Porém, fica claro ao longo da peça que a intenção de Maria Stuart ao fugir para a Inglaterra era de simplesmente encontrar abrigo na casa de sua prima, e não de lhe usurpar o poder. Quando condenada à morte pela rainha inglesa, ela o é por um fator externo à sua culpa: ela seria condenada por ser uma ameaça à rainha da Inglaterra, por algo que na verdade não fazia parte de sua vontade. A morte é um ato de purificação que traz de volta à personagem a tranquilidade que a culpa não deixa emergir. Ela é a forma de expiar a culpa primeira de Maria Stuart, a morte de seu marido, e não um ato injusto do destino. Dessa forma, a morte da heroína personifica o triunfo da liberdade sobre a existência, pois possibilita a Maria Stuart o ápice da perfeição e harmonia, tornando a existência apenas o meio para se atingir o fim moral: "o sacrifício da vida a serviço de um objetivo moral ganha um alto sentido final, porque a vida nunca é importante por si mesma, como fim, mas tão-só como meio para os fins morais" (SCHILLER, 1991, p. 24).

Nesta peça, não podemos entender a morte como infortúnio: a situação trágica da rainha escocesa exige que esta aconteça para se atingir o fim moral. Maria Stuart é caracterizada como um ser virtuoso que encontra na adversidade o caminho exato para a sublimação. Ela é a representação da culpa que necessita renunciar à natureza para atingir um estado superior e assim alcançar a liberdade moral. Sentimos o prazer estético de que fala Schiller no momento em que presenciamos a força e a nobreza da heroína ao abrir mão de lutar por sua existência física e rumar com coragem, serenidade e firmeza para a morte. Esta inadequação de sentimentos é adequada, na media em que sentimos prazer na sublimação que o ser alcança com a morte. Sua dignidade e valor mítico se expandem perante o leitor/espectador, atingindo a formação moral de que fala o autor. É o prazer na compaixão que sentimos pela rainha da Escócia que ativa essa faculdade moral, que entra em confronto com este sentimento e intensifica nossa apreciação artística da dor da personagem.

Do mesmo modo, a heroína da peça Die Jungfrau von Orleans, Johanna, abandona sua vida para atingir o fim moral que sua liberdade the proporciona diante do sensível. De grande êxito à época de sua representação, a peça retoma a famosa história da jovem camponesa de 17 anos que no ano de 1429 (SAFRANSKI, 2006, p. 475) resolve partir para Orleans no intuito de ajudar o exército francês que estava sendo massacrado pelos ingleses na Guerra dos Cem Anos. Joana d'Arc ficou conhecida como a donzela que, inspirada pelo divino, obteve êxito ao 
libertar a cidade de Orleans do domínio inglês e conduzir o rei Carlos VII vitorioso à sua coroação na cidade de Reims, sendo posteriormente capturada pelo exército inglês e queimada como bruxa no ano de 1431 . Segundo Safranski (2006), Schiller ficou tão impressionado com o magnetismo dessa história que se empenhou em estudá-la a fundo, fazendo de Joana d'Arc a sua heroína.

Schiller segue alguns dados da história oficial e subverte outros, resgatando a figura da heroína Joana D’Arc de forma a santificá-la. A peça também se passa durante a Guerra dos Cem Anos e nos conta a história de uma jovem, que segundo seu pai, era uma menina peculiar, que sempre vivera afastada de todos da sua família, passando a maior parte de seu tempo ao lado de uma árvore cuidando dos animais da fazenda, como que em um transe profundo. Um dia, chega à fazenda de seu pai um outro fazendeiro de nome Bertrand com notícias sobre a tomada de Orleans pelos ingleses, portando em suas mãos um elmo. Johanna, ao ver esse objeto, fica inquieta e tenta de todas as formas apoderar-se dele, e quando finalmente consegue e o coloca em sua cabeça, é como se um poder mágico fosse incorporado a ela. Em um monólogo, ela explicita que Deus apareceu para ela em sonho e lhe ordenou que, quando tivesse em sua posse um elmo, fosse a Orleans para salvar o reino francês de rei Carlos, porém, para sair vitoriosa do campo de batalha, a heroína deveria renunciar a qualquer ato humano que não fosse executado com o pleno consentimento do espírito que a guia. Ao chegar à guerra, ela move os exércitos com tamanha facilidade, que batalha após batalha é garantido aos soldados o ímpeto para a vitória.

Porém, mesmo nesse estado de transe em que apenas o divino se deixa mostrar, Johanna já começa a mostrar indícios de enfraquecimento diante de sua consciência moral, e, ao se deparar com Lionel, um comandante inglês, Johanna empreende um combate com ele e, dominando-o, arranca-lhe a armadura que lhe cobre o rosto e olha em seus olhos (SCHILLER, 2011, p. 91):

ergreift ihn von hinten zu am Helmbusch und reißt ihm den Helm gewaltsam herunter, daß sein Gesicht entblößt wird, zugleich zückt sie das Schwert mit der Rechten. [...] In diesem Augenblick sieht sie ihm ins Gesicht, sein Anblick 
ergreift sie, sie bleibt unbeweglich stehen und läßt dann langsam den Arm sinken. ${ }^{4}$

A indicação de cena no texto mostra que Johanna "se comove" com a feição de Lionel, o que indica que a impetuosidade com que o divino a fazia matar qualquer adversário que lhe fizesse frente é imediatamente substituída por sua humanidade, que recobra seus direitos. Para Johanna é impossível matar a quem lhe comoveu pelos olhos; ela reconhece nos olhos de sua presa a sua própria humanidade, e isso faz com que a heroína abandone o impulso divino que a fazia lutar sem piedade. Porém, ao recobrar a consciência de seus atos, Johanna fica extremamente perturbada, pois essa comoção por um homem fez com que ela desobedecesse à ordem divina; seu lado humano prevaleceu, dando ao livre arbítrio espaço suficiente para tomar para si o poder.

A queda de Johanna e sua descrença na capacidade de continuar sua missão a partir desse momento é evidente: a heroína é marcada pela culpa de ter deixado sua humanidade prevalecer à sua destinação divina, e se acha indigna de carregar o estandarte, sua armadura, sua espada, e até mesmo de conduzir o rei em sua vitória perante o povo de Reims. Porém ela o conduz à festa da vitória, mas seu pai, que ali estava para desmascarála, aparece e diz que ela serve ao demônio. O rei, estarrecido com a revelação, suplica a Johanna que se defenda e que diga que sua motivação partiu do reino dos céus, porém a virtude da heroína lhe impede a defesa, pois essa punição vem para ela como forma de expiar sua culpa de traição ao divino, assim como em Maria Stuart a morte a purifica do homicídio cometido anteriormente.

Impossibilitado de dar a Johanna uma punição mais severa, o rei ordena à heroína que se retire daquele local, porém na fuga ela é capturada pelos ingleses. Ao ser aprisionada, os seus inimigos a inflamam de ódio na medida em que lhe descrevem o quanto seus exércitos estão sendo massacrados sem a sua ajuda, e o ápice se dá quando Johanna ouve que seu rei está prestes a ser abatido na batalha. Nessa cena, já não mais o divino a acompanha e, por força de sua vontade, Johanna se desfaz das cadeias que a prendiam e consegue partir para o campo de batalha para salvar seus exércitos. É nessa batalha que seu poder de encantamento

\footnotetext{
4 “agarra-o por trás pela crista do elmo e o arranca com violência, deixando seu rosto exposto, ao mesmo tempo ela puxa a espada com a mão direita. [...] Neste momento (em que vai feri-lo) ela vê seu rosto, seu olhar a comove, ela permanece imóvel e, então, baixa lentamente seu braço.”
} 
parte de sua livre vontade, e a dignidade da ação se dá por essa imposição da vontade diante da necessidade de auto conservação que se torna adequada moralmente (Zweckmäßigkeit). Ela morre salvando sua pátria.

Transpondo para os termos filosóficos utilizados por Schiller (2002) na descrição dos impulsos, vemos que Johanna passa por dois impulsos para atingir o suprassensível: o primeiro é o impulso formal, em que o ser, livre de limitações, se amplia de tal forma que se torna imutável e eterno - por isso a configuração divina dada à personagem; o segundo é o impulso sensível, em que o ser é limitado e torna-se matéria, sendo dominado pela sensibilidade; quando finalmente estes impulsos são harmonizados, a beleza do jogo transparece e através dela os impulsos são dominados pela imposição da categoria suprassensível, a vontade.

O herói trágico, segundo Schiller (1992) enfrenta o despotismo dos instintos impondo sua vontade acima de qualquer ato de autoconservação; através da representação desse embate, vemos a liberdade moral desfilar diante de nossos olhos, transparecendo na representação o suprassensível, o invisível. As personagens Johanna e Maria Stuart personificam esse embate de impulsos em que a vontade prevalece. Maria Stuart cai em desgraça porque desequilibrou a harmonia geral, ou seja, suas ações levaram-na a praticar um ato que desestruturou a ordem estabelecida. Entretanto, para que ela seja reconhecida pelo público como heroína, precisa legitimar-se como alguém capaz de sentir antes mesmo de aparecer como ser racional. Ela precisa demonstrar que sua alma sente "o sofrimento intensa e intimamente" (SCHILLER, 1992, p. 116), mas que há uma carga de racionalidade que lhe permite não ser subjugada e dominada pelo amor que sente pela vida, pois quando o sacrifício dela se faz necessário, deverá demonstrar coragem e autodeterminação para submeter-se com honra a seu destino trágico. Já na personagem Johanna, Schiller concilia a selvageria da guerra e a delicadeza bela de uma donzela de dezessete anos, que, movida por uma instância divina, age também de forma divina. É interessante notar que a divinização inicial da heroína foge ao status do herói trágico descrito por Schiller. Segundo Kant (1992, p. 71, nota no 23),

É, sem dúvida, uma limitação da razão humana, que nem sequer dele se há-de separar, o facto de não podermos pensar valor moral algum de importância nas acções de uma pessoa sem, ao mesmo tempo, tornar humanamente representável esta pessoa ou a sua manifestação [...]; com efeito, a fim de para nós tornarmos apreensíveis qualidades 
sobrenaturais, precisamos sempre de uma certa analogia com seres naturais. Por isso, um poeta filósofo atribui ao homem, enquanto tem de combater em si uma propensão para o mal, e inclusive por si mesmo, contanto que a saiba vencer, uma posição mais elevada na escala moral dos seres do que aos próprios habitantes do céu, os quais, em virtude da santidade da sua natureza, estão subtraídos a toda sedução possível.

Para Kant, o poeta-filósofo ao mesmo tempo em que aproxima seus heróis da figura humana, também os diviniza, tornando-os todos semelhantes à imagem de Jesus, por exemplo, que são tentados, mas conseguem agir de forma moral, buscando alcançar o divino. Afora a propensão para o mal, da qual Schiller discorda de Kant, a elevação do personagem ao divino é para Schiller algo que também necessita de uma aproximação com o humano, pois o seu completo afastamento repele a figura do personagem do leitor/espectador, impedindo uma identificação.

Para o autor (1992), os heróis muito virtuosos não são recomendados, pois quando o são em demasia afastam a participação do espectador na identificação com o mesmo. Em contrapartida, essa identificação não pode ser exagerada, já que é necessário que se mantenha um certo distanciamento para que o espectador não se deixe levar pelo exacerbamento de sentimentos. Ele deve conservar a sua plena liberdade para que consiga fruir o prazer que o sublime proporciona, e o dramaturgo deve manter uma variação dos sentimentos suscitados pela tragédia para que o distanciamento seja sustentado. Dessa forma, o poder imaginativo do leitor/espectador permanece ativo e não o faz sucumbir pela emoção, que lhe tira o prazer da fruição estética. A liberdade dos sentidos é essencial.

Por isso, após a divinização inicial da heroína Johanna, Schiller nos mostra a fraqueza, a emersão da natureza sensível da personagem, que em um momento de fúria deixa transparecer sua humanidade. Ao ver-se novamente como alguém que é movida também por necessidades físicas, em que o sofrimento alcança o racional, quando vê que sua culpa ao matar os inimigos é maior do que essa força divina que penetrou seu corpo, ela é abandonada pelos deuses, e é nesse abandono que a heroína percebe a sua força, a sua liberdade enquanto ser moral, pois é a partir da imposição da sua vontade, do enfrentamento do sensível por essa vontade que a faz quebrar a ligação com o divino que a limitava e lutar por aquilo que se tornou o seu ideal, não mais influenciada pelo divino, mas sim 
livre para a sua decisão moral. Ela se torna autônoma. É como se ao atuar sob a influência divina, a heroína não tivesse liberdade, fosse apenas um corpo que se deixa levar pelo divino, uma marionete kleistiana que só se movimenta quando o seu Deus se dispõe a emprestar-lhe a alma; ao recobrar a sua liberdade, ela expõe toda a força que o seu caráter possui, ou seja, a verdadeira liberdade. A primeira influência (divina) acontece do externo para o interno; a segunda (moral) ocorre do interno para o externo, e, por isso, é mais verdadeira.

Dessa forma, as heroínas de Schiller passam por todas as privações e mesmo assim a serenidade e capacidade de liberdade de ambas nos surpreendem devido à nobreza de suas ações. Elas renunciam aos interesses vitais através de uma livre opção moral, aceitando conscientemente os males que sofrerão. É a possibilidade de encontrar no herói essa vontade totalmente livre, corajosa e autodeterminada que, na visão de Schiller, agrada nosso gosto estético: o personagem sofre, mas resiste bravamente aos instintos de autoconservação porque sua livre vontade dá forças para esta resistência, revelando seu lado digno e comprovando que a sua destinação espiritual ultrapassa a transitoriedade da existência.

O herói sofre, mas resiste diante da magnitude de seu caráter moral: ele repete sua vida de desgraça no palco e serve de exemplo aos que o assistem. Dessa maneira é que Schiller irá caracterizar a tragédia como uma instituição moral. O teatro, que se utiliza de meios morais para proporcionar o entretenimento, pode ser entendido então como um "auxiliar" da justiça, mas mais potente que suas leis, pois age no âmago do ser humano: "Nosso prazer ante o belo, o comovente e o sublime fortalece os nossos sentimentos morais" (SCHILLER, 1992, p. 16). O palco nos familiariza com os destinos humanos, com o acaso e nos dá os meios que fazem com que mantenhamos a nossa vontade diante de imposições. Mesmo diante dos males a que são submetidos os heróis trágicos, nos entretemos porque a liberdade com que eles enfrentam esses males são superiores ao seu bem-estar; eles renunciam aos interesses vitais através de uma livre opção moral, o que nos faz sentir nessa capacidade de liberdade do herói a nossa própria. A desgraça fictícia, o patético, segundo Schiller (1992), "põe-nos em direta relação com a lei dos espíritos que impera em nosso peito" (SCHILLER, 1992, p. 67). Por ser fictícia, ela nos encontra preparados, pois nos atinge como mero produto da imaginação. Ao nos familiarizarmos com esta desgraça através do teatro, ganhamos, segundo o autor, vantagem no mundo sensível, pois a partir do momento que ela se torna real, estamos preparados para enfrentá-la. O nosso coração, na 
30 | Carina Zanelato Silva

ficção, vivencia esta desgraça, mesmo que de forma mais amena: "Por essa razão, pode dizer-se que o patético é uma inoculação do destino inevitável, pela qual é privado de sua malignidade, já que o ataque desta é conduzido contra o lado forte do homem" (SCHILLER, 1992, p. 67).

Disso depreendemos que o sofrimento, para Schiller, é a chave da libertação da alma humana, e é através dele que conseguimos alcançar o domínio da moral sobre o sensível. E a vontade moral só nos agrada na medida em que atinge o objetivo de libertar o homem; clamamos pelo entretenimento, pelo efeito estético libertador. A arte é formadora na medida em que, como imitadora, consegue atingir o coração do homem livre de limitações. Ela o expõe a uma situação que poderia ser real, causa nele o efeito sublime através de um personagem que age de forma sublime, e lhe garante a vantagem de estar preparado caso o destino funesto se torne real. Nesta relação entre realidade e arte, a arte, por preparar o homem para a realidade, se torna superior a esta na formação do homem.

Safranski (2006, p. 478) diz que à época de Schiller a peça Die Jungfrau von Orleans foi recebida com grande entusiasmo e que a esse entusiasmo se mesclaram os primeiros sentimentos patrióticos, contrários à expansão do império napoleônico na Alemanha (SAFRANSKI, 2006, p. 478):

El público no veía en La doncella de Orleans no sólo una pieza mágica de tipo romántico, sino que además percibía en ella un mensaje político. En la figura de la mística militante veía el renacimiento nacional de Francia. ¿No habría necesidad también en Alemania de semejante figura con dotes de caudillo carismático? Schiller había suscitado en el escenario el encanto de una política salvadora.

Prestes a entrar sob o domínio napoleônico, a Alemanha fragmentada da época de Schiller se vê diante de uma força externa que pretende se estabelecer como governante do país, assim como na peça vemos Johanna lutar contra forças externas que dominavam a França durante a Guerra dos Cem Anos. E o cenário não poderia ser mais propício: como um país que lutou para ser governado pelos seus pode querer impor seus domínios sobre outros países? A perspicácia com que Schiller abordou o tema e elevou a figura de Joana D'Arc à categoria de mártir, figura essa anteriormente categorizada por Shakespeare como bruxa e satirizada por Voltaire, dão o tom da tentativa de Schiller de 
promover a revolução através da arte. A literatura intenta na prática o que a teoria na filosofia propõe.

Disso resulta que, na ótica de Schiller, o ponto central é entender como a arte se comporta em relação ao espírito humano e em relação ao seu momento contemporâneo, e a Revolução Francesa despertou nos intelectuais da época o interesse em se descobrir o que era realmente a Alemanha. Para tanto, Schiller (1992) adentra a categoria do histórico e nos diz que na história encontramos "cenas patéticas da humanidade em luta com o destino, da irresistível fuga da felicidade, da segurança burlada, da injustiça triunfante e da inocência vencida" (SCHILLER, 1992, p. 68), que podem nos fornecer material suficiente para a reflexão do momento contemporâneo. Como objeto sublime, a história é para Schiller (1992, p. 68) um abalo sísmico que destrói, reconstrói e destrói novamente, configurando a luta da humanidade contra o destino, que nos arremessa em direção à felicidade para trazernos o infortúnio ou vice-versa. A arte trágica aproveita-se dos atos sublimes que provêm da história para, imitando, instigar a nossa capacidade de sentir o sublime, e o referencial histórico funciona, dentro da obra artística, como um símbolo do real.

Schiller (1992) parte da premissa aristotélica de que a tragédia não deve reproduzir o fato histórico assim como aconteceu: ao invés disso, ela deve, como forma de alcançar o fim poético, reproduzir uma ação que deleite a partir da comoção (SCHILLER, 1992, p. 107):

Ao tratar, pois, de uma dada matéria segundo esse seu fim, torna-se, por isso mesmo, livre na imitação. Obtém o direito e até a obrigação de subordinar a verdade histórica às leis da arte poética e de trabalhar a matéria dada segundo suas necessidades.

Daí resulta que não cabe ao poeta ater-se ao fato histórico de forma fiel: é preciso que os acontecimentos e os personagens sejam moldados de acordo com as necessidades do assunto trágico e da verossimilhança. A arte criadora não é limitada pelas amarras da natureza, e nisto ganha porque faz com que o espectador seja livre diante do objeto sublime e belo: o que é imitação, não-realidade, atinge o homem na aparência, deixando-o livre do poder devastador da natureza, que se torna objeto de livre observação. Para Schiller (1992), é esse abandono do real que torna a arte verdadeira e ideal; por conseguinte, o escritor não deve utilizar-se do real (neste caso, da história) tal como o encontra no mundo 
extraliterário, mas deve buscar o ideal na produção de todas as partes da arte.

Exemplos do uso de temas provenientes da história são encontrados facilmente na obra de Schiller. Em seus dramas históricos, o autor trata de fatos e personagens verídicos que foram importantes para a definição ou para o fortalecimento de seus respectivos países em termos da criação de uma identidade nacional ou sentimento de nação: Elizabeth I em relação à Inglaterra (na peça Maria Stuart), Joana D’Arc na França (Die Jungfrau von Orleans), Felipe II na Espanha (Dom Carlos), etc. Como se vê, em Maria Stuart o período abordado é o das tensões religiosas (entre Igreja Católica, Protestantes e Anglicanos); em Die Jungfrau von Orleans, a época é a da ocupação inglesa em solo francês; em Dom Carlos, a Espanha redefinia seus laços com as coroas portuguesa e austríaca, e tornava-se potência econômica mundial. Schiller critica em seus dramas o excesso e o abuso de poder e busca, através dessa crítica, refletir sobre seu próprio contexto. Essa identificação dos temas à situação histórica tem como foco a teoria do autor de que é no mundo estético que se dá a formação do homem, e é a partir daí que ele se liberta no mundo físico e consegue validar a sua liberdade, atingindo, assim a capacidade de ser livre e crítico à sua situação atual.

A teoria estética de Schiller se materializa na produção literária do autor, que consegue inserir em suas tragédias o homem percorrendo os três níveis - físico, estético e moral - para chegar à liberdade moral, ou seja, à sua sublimação. Em suas peças, sentimos o prazer estético de que fala Schiller no momento em que presenciamos a força e a nobreza de seus personagens, que lutam contra os impulsos de auto-conservação através da força moral que lhes é própria. $O$ herói trágico clássico é aquele que se encontra em uma situação-limite e, nela, expande sua potência de herói, superando sua natureza; ele atira-se ao mundo da liberdade espiritual, caracterizando o triunfo da idéia, da reflexão sobre o impulso natural.

As heroínas de Schiller são parâmetro para entendermos essa ideia de homem clássico na medida em que suas ações são permeadas por uma racionalidade que busca controlar os ímpetos e que reconhece na harmonia a liberdade só pode ser alcançada através do equilíbrio. Sentimos a inadequação sensível sendo superada pela adequação moral e nos sublimamos a partir da capacidade moral dos personagens. Dentro dos moldes do teatro clássico, a dignidade de cada herói se expande perante o leitor/espectador, atingindo a formação moral: eles enfrentam seus impulsos para atingir a liberdade moral no suprassensivel e partilham 
essa experiência com o leitor/espectador, que vê no herói a sua possibilidade de liberdade.

Se a normatização da forma em Schiller, traduzida numa tentativa de manutenção da forma antiga, é fortemente marcada por essa característica ideal que a arte carrega em sua teoria estética, já é possível notar uma pequena interferência de questões externas, históricas no bojo de sua forma dramática. A forma trabalha de maneira a proporcionar o efeito estético libertador, mas muito embasada ainda nos parâmetros da forma antiga, fixa, pré-estabelecida.

Assim, a arte é para Schiller a chave para a educação do homem. É em estado lúdico que homem sente a liberdade, em que o nobre ou o escravo possuem os mesmos direitos. "No reino da aparência estética, portanto, realiza-se o Ideal da igualdade, que o fanático tanto amaria ver realizado também em essência” (SCHILLER, 2002, p. 141), ou seja, a estética realiza em essência as pretensões de um povo que não soube lidar com a liberdade e que, por isso, transformou o ideal de igualdade e fraternidade em terror. Literatura e filosofia se unem em Schiller com o propósito de proporcionar ao homem a capacidade para a liberdade, e o teatro tido como instituição moral instiga essa nossa capacidade de sentir o sublime e nos encaminha para a reflexão diante do mundo.

\section{REFERÊNCIAS BIBLIOGRÁFICAS}

BARBOSA, R. Schiller e a cultura estética. Rio de Janeiro: Jorge Zahar Editor, 2004. (Filosofia Passo a Passo, 42).

KANT, I. A religião nos limites da simples razão. Tradução de Artur Morão. Coimbra: Edições 70, 1992

- Crítica da faculdade do juizo. Tradução de Valerio Rohden e António Marques. 2a edição. Rio de Janeiro: Forense Universitária, 2002.

KORFMANN, M. Kant: autonomia ou estética compromissada? Pandaemonium Germanicum, São Paulo, v. 08, p. 23-38, 2004.

RÖHL, R.; Heise, E. História da literatura alemã. São Paulo: Ática, 1986.

ROSENFELD, A. História da literatura e do teatro alemães. São Paulo: Perspectiva / Edusp; Campinas: Edunicamp, 1993. (Debates 255)

SAFRANSKI, R. Schiller o la invención del idealismo alemán. Traducción de Raúl Gabás. Barcelona: Tusquetes, 2006. 
. Romantismo: uma questão alemã. Tradução de Rita Rios. São Paulo: Estação Liberdade, 2010.

SCHILlER, F. Maria Stuart. Tradução de Manuel Bandeira. Rio de Janeiro: Civilização Brasileira, 1955.

- Teoria da tragédia. Introdução e notas Anatol Rosenfeld. São Paulo: E. P. U., 1992. (Biblioteca Pólen)

- A educação estética do homem: numa série de cartas. Tradução de

Roberto Schwarz e Márcio Suzuki. São Paulo: Iluminuras, 2002.

. Die Jungfrau von Orleans: eine romantische Tragödie. Stuttgart:

Reclam, 2002.

- Kallias ou sobre a beleza. A correspondência entre Schiller e Körner em janeiro e fevereiro de 1793. Tradução e introdução de Ricardo Barbosa. Rio de Janeiro: Jorge Zahar Editor, 2002.

. Sobre poesia ingênua e sentimental. Tradução, introdução, comentário e glossário de Teresa Rodrigues Cadete. Lisboa: Imprensa Nacional - Casa da Moeda, 2003.

. Fragmentos das preleções sobre estética do semestre de inverno de 1792 -

93. Recolhidos por Christian Friedrich Michaelis. Tradução e introdução de Ricardo Barbosa. Belo Horizonte: Editora UFMG, 2004.

. Sobre graça e dignidade. Tradução de Ana Resende. Porto Alegre: Movimento, 2008.

SZONDI, P. Teoria do drama moderno: 1880-1950. Trad. Luiz Sergio Repa. São Paulo: Cosac \& Naify, 2001.

Recebido em 28 de julho de 2016.

Aceito em 10 de dezembro de 2016. 